\title{
AS PRETAS MINA E OS USOS DA ESCRITA EM MINAS COLONIAL: MARIANA 1711-1760
}

\author{
Vivian Felipe de Sousa*, Aldair Carlos Rodrigues.
}

\begin{abstract}
Resumo
A pesquisa trata das relações das comerciantes africanas da Costa da Mina com as múltiplas formas de uso da palavra escrita nos arraiais auríferos de Mariana, Minas Gerais, na primeira metade do século XVIII. O grupo de mulheres investigado, são denominadas Minas, por se tratar de mulheres forras e escravizadas, que vieram da costa da Mina, na África Ocidental. Essas donas, se destacaram no comércio acumulando, em alguns casos, riqueza, através das vendas de tabuleiros no abastecimento das cidades. Com isso, as relações sociais delas foram marcadas por ambiguidades em que foi necessário lidar com o poder assimétrico da sociedade escravista, com as clivagens sociais, o controle social e quando forras - com a liberdade precária. Dentro desse contexto, a pesquisa tem o objetivo de encontrar o protagonismo e agência das mulheres mina, através da cultura escrita, documentação oficial da colônia, e as redes sociais que elas teciam, a dimensão social que permeou o cotidiano dessas mulheres, que apesar de analfabetas, encontram um lugar de protagonismo na história por meio dos testamentos, cartas de alforria, almotaçarias, livros de notas, etc.
\end{abstract}

\section{Palavras-chave: \\ Mulheres Africanas, Minas Colonial, Diáspora}

\section{Introdução}

As pretas minas, mulheres que protagonizaram no comércio interno da colônia em diversos arraiais auríferos em Minas Gerais, foram mulheres que se destacaram, por deixarem documentações e inventários que apresentam seus acúmulos como mulheres alforriadas que alcançaram uma certa riqueza material através das vendas de tabuleiros. A historiografia tem olhado paras as pretas mina, como sujeitos de ação, que possuem controle sociais e culturais de suas vidas, que trazem consigo um acúmulo de conhecimento trazido de suas experiências anteriores no continente africano, evidenciando a importância de uma construção historiográfica interconectada, com o cuidado de não ser uma história das mulheres vista apenas por uma perspectiva essencialista. Trata de uma construção de muitas histórias entrelaçadas e diversa. É importante entender que apesar de tratar de um grupo de mulheres - pretas mina - evidentemente, não se deve cair em generalizações, que descartam as diversidades dos acontecimentos, algumas mulheres minas, se destacaram, subverteram a hierarquia social existente, mas não são uma massa homogênea em que todas se saíram da mesma forma dentro do contexto de escravização de seus corpos. São mulheres que se expressaram quantitativamente em relação ao acesso às alforrias, apesar de, as mulheres serem cerca de $30 \%$ do contingente de pessoas que chegaram à colônia, são elas as que se destacam na compra de alforrias e no acúmulo de pecúlio e riqueza através das vendas e das atividades mercantis. Diante disso, a importância de entender e observar a apropriação da cultura escrita e dos aparatos burocráticos manipulados por essas mulheres analfabetas.

\section{Resultados e Discussão}

A documentação apresenta o predomínio de mulheres forras vinda da Costa da Mina no comércio de Mariana no período estudado, sendo cerca de $90 \%$ do total de mulheres forras comerciantes ${ }^{1}$. Também encontramos dados que demonstram que as relações delas, eram majoritariamente com outras mulheres, como a compra de escravas por exemplo. No comércio, as mulheres se destacam em detrimento dos homens, salientando as teses de incorporações das relações de gênero trazidas de suas experiências africanas. Tais africanas, não são alfabetizadas, mas manipulam as burocracias existentes na colônia com destreza e zelo entendendo a importância dos documentos escritos, para salvaguarda de suas conquistas e direitos, como alforrias, recibos de compras e vendas.

\section{Conclusões}

Encontrar as mulheres minas na documentação oficial da colônia, evidenciam sua existência e constata sua agência e estratégias de sobrevivência dentro da sociedade escravista, permeado pelo estigma social da cor e do gênero. Mas mais que isso, evidenciam, os domínios que elas exerceram acerca das burocracias existentes, o entendimento sobre a importância do registro e da cultura escrita. Através dessas redes e desses papéis, é possível, dentro dos limites, entender como elas se mobilizaram e viveram. Além disso, é uma forma de fazer um movimento de memória² e acessar as particularidades das dinâmicas de suas vidas, suas relações sociais e ações históricas. Percorrer a memória dessas mulheres, e ressignificar suas existências, é vêlas transgredindo as hierarquias sociais existentes.

\section{Agradecimentos}

Agradeço a CNPq (Conselho Nacional de Desenvolvimento Científico e Tecnológico) pela bolsa de pesquisa e auxílio financeiro que possibilitou a dedicação.

1 PUFF, Flavio Rocha. Os pequenos agentes mercantis em Minas Gerais no século XVIII: perfil, atuação e herarquia (1716-1755) (dissertação) UFJV. Juiz de Fora. 2007

${ }^{2}$ SCOTT, Rebecca J. Provas de liberdade: uma odisseia atlântica na era da emancipação. Coautoria de Jean M. Hébrard. Tradução de Vera Joscelyne. Campinas, SP: Editora da Unicamp, 2014. 292 p., il. ISBN 9788526810693 (broch.). 